\title{
Short Communication: A comparative study of phenotypes and starch production in sago palm (Metroxylon sagu) growing naturally in temporarily inundated and non inundated areas of South Sorong, Indonesia
}

\author{
TOMAS YATER ${ }^{1}$, HERMAN WAFOM TUBUR ${ }^{2}$, CIPTA MELIALA ${ }^{2}$, BARAHIMA ABBAS $^{2,}$ \\ ${ }^{1}$ Graduate Program, Universitas Papua. Jl.Gunung Salju, Manokwari 98312, West Papua, Indonesia. \\ ${ }^{2}$ Faculty of Agriculture, Universitas Papua. Jl.Gunung Salju, Manokwari 98312, West Papua, Indonesia. ”email: b.abbas@unipa.ac.id
}

Manuscript received: 6 December 2018. Revision accepted: 25 March 2019.

\begin{abstract}
Yater T, Tubur HW, Meliala C, Abbas B. 2019. Short Communication: A comparative study of phenotypes and starch production in sago palm (Metroxylon sagu) growing naturally in temporarily inundated and non-inundated areas of South Sorong, Indonesia. Biodiversitas 20: 1121-1126. Sago palm forests and sago palm semi cultivation are generally spread in swampy areas, seasonally inundated areas and non-inundated areas. The objectives of this study are to determine and compare the phenotypes of and starch production by sago palms growing naturally in the temporarily inundated areas (TIA type) and non-inundated areas (WIA type) in South Sorong District, West Papua Province, Indonesia. Sago palms of both habitats were found to be the same variety based on analysis of vernacular names and general characteristics. Comparison of morphological characters related to starch production of TIA and WIA types showed that there were no significant differences between the two studied types. The distribution of starch along the sago trunk was observed to be uneven, higher starch accumulation was found in the middle part of the trunk which was significantly different from the lower and upper parts of the trunk.
\end{abstract}

Keywords: Inundated areas, phenotypes, production, sago palm, South Sorong

\section{INTRODUCTION}

Sago palm (Metroxylon sagu Rottb.) is an economically and culturally important plant in Papua and West Papua provinces of Indonesia. Besides serving as the major source of edible starch, sago palm is also an integral part of the culture of the Papuan people. According to Kertopermono (1996), the total area under sago palm cultivation in Indonesia reached $15,28,917$ ha out of which about $14,06,469$ ha was located in Papua. Papua Province and West Papua province of Indonesia estimated to have 1.2 million hectares of sago palm forests and another 14,000 hectares of sago palm under semi cultivation (Flach 1997). The investigation conducted by BPPT (2014) showed that the area of sago palm forest cover in South Sorong reached 311,591 ha which is approximately $44.88 \%$ of the total area of the district. These sago palm areas are spread in eight districts, namely Seremuk, Saefi, Konda, Kais, Metamani, Inanwatan, Kokoda, and North Kokoda (Ihalauw 2015). Trunk formation of sago palm is divided into three stages, namely before or pre-harvesting stage, harvesting stage, and post-harvesting stage. The average density observed before harvesting stage was 87 trees $\mathrm{ha}^{-1}$, at harvesting stage was 68 trees/ha, and post-harvesting stage was 18 trees ha $^{-1}$, approximately (Ihalauw 2015).

The total populations of sago palm were estimated around 27 million trees in the trunk stage, 21.1 million trees in harvesting stage and 5.5 million trees in over- harvesting stage. Average trunk diameter and trunk height of sago palms growing in the South Sorong region were measured at $41.4 \mathrm{~cm}$ and $10.7 \mathrm{~m}$, respectively (Ihalauw 2015). In general, the sago palms are regularly found growing in inundated areas such as on river banks and muddy soils (Notohadiprawiro and Louhenapessy 1992). However, Sago palm can also grow in marginal lands with low $\mathrm{pH}$ and areas that are often inundated. Sago palms were reported to produce around $200-400 \mathrm{~kg}$ of dried starch per trunk (Bintoro et al. 2007). In the South Sorong region, sago palms are found growing in swampy areas and mineral soil rich areas (BPPT 2014). Furthermore, in Saifi District, South Sorong, sago palm was found growing in areas without any inundations (Dewi et al. 2016).

Differences in environmental conditions affect the growth and production of sago palms. Growth of sago palms in dry land is generally slower than the growth of sago palms in the temporarily wetland. Notohadiprawiro and Louhenapessy (1992) reported that formation of sago palm trunks is very slow in permanently inundated areas and it also affects the starch production trunk, while growth and production of sago palms in land with periodic flooding and non-flooding is better. Flach (1983) also affirmed that inundated conditions also affect the growth and formation of suckers. Growth performance of natural stands of sago palms in temporarily flooded and nonflooded areas is worth studying. The objectives of this study were to compare the morphological characters of and 
starch production by sago palms growing in temporarily inundated areas (TIA) and without inundation areas (WIA) of South Sorong District, Indonesia.

\section{MATERIALS AND METHODS}

\section{Sample location}

The study was conducted in the Nakna Village of Konda District and Wayer Village of Wayer Distrik, South Sorong District, West Papua Province, Indonesia from January to April 2018. Majority of sago palms grown in the Nakna Village was found to be of temporarily inundated areas (TIA) type and majority of palms in the Wayer Village belonged to the without inundation areas (WIA) type. Based on field observations, vernacular names and opinion of local people, it was confirmed that the sago palms growing in both areas were of the same variety. Forest stands of sago palms in South Sorong were reported to be almost of the same type (Abbas et al. 2014). The geographical position of sampling locations is presented in Table 1 and the sample palms are shown in Figure 1. Study samples in each location involved three mature trunks of sago palm. Sago palms selected as samples were cut down by using chainsaw and the diameter and the length of the sago palm trunk were measured using a meter roll. The weight of the trunk, pith, and starch were determined by using weighing scale. The pith was shredded using a shredder machine and the starch was extracted manually.

\section{Statistical analysis}

The study used descriptive methods and statistical analysis. Observation method was used to describe the morphological characters and their ability to accumulate starch in the trunk. Each sample palm was cut and divided into 3 parts, namely bottom, middle and upper trunk, and then extracted. Morphological quantitative variables of sago palm samples of TIA and WIA types were analyzed using statistical methods. Significance level of the data was calculated by using Analysis of variance performed by using SAS version 9.1. Data regarding starch accumulation in the lower, middle and upper trunk sections were also statistically analyzed.

\section{RESULTS AND DISCUSSION}

\section{Morphological characteristics}

Comparison of the morphological characters of sago palms of TIA and WIA types indicated that there are no differences in overall values (Table 2). The surface color of the midrib was green and spiny in both types (TIA and WIA types). The size of the spines on the midrib in the rosette stages was longer, but in the trunk phase, no spines were present (Figure 2). The trunks were cut approximately 1 meter from the surface of the ground. The surface of the trunk appeared reddish brown in the first layer and the second layer appeared white in color (Figure 3.B).

Table 1. Geographical locations of sago palms that were used as samples

\begin{tabular}{lccc}
\hline \multicolumn{1}{c}{ Areal types } & $\begin{array}{c}\text { No. of } \\
\text { palms }\end{array}$ & Geographical positions & $\begin{array}{c}\text { Altitude } \\
\text { (m asl.) }\end{array}$ \\
\hline Temporarily & 1 & $1^{\circ} 34^{\prime} 16.1^{\prime \prime} \mathrm{S}-132^{\circ} 00^{\prime} 34.6^{\prime \prime} \mathrm{E}$ & 43 \\
inundated & 1 & $1^{\circ} 34^{\prime} 18.2^{\prime \prime} \mathrm{S}-132^{\circ} 00^{\prime} 37.2^{\prime \prime} \mathrm{E}$ & 43 \\
areas (TIA) & 1 & $1^{\circ} 34^{\prime} 15.1^{\prime \prime} \mathrm{S}-132^{\circ} 00^{\prime} 33.3^{\prime \prime} \mathrm{E}$ & 43 \\
Areas & 1 & $1^{\circ} 28^{\prime} 02.2^{\prime \prime} \mathrm{S}-132^{\circ} 02^{\prime} 28.2^{\prime \prime} \mathrm{E}$ & 39 \\
without & 1 & $1^{\circ} 28^{\prime} 07.6^{\prime \prime} \mathrm{S}-132^{\circ} 00^{\prime} 13.4^{\prime \prime} \mathrm{E}$ & 48 \\
$\begin{array}{l}\text { inundation } \\
\text { (WIA) }\end{array}$ & 1 & $1^{\circ} 28^{\prime} 12.0^{\prime \prime} \mathrm{S}-132^{\circ} 03^{\prime} 03.1^{\prime \prime} \mathrm{E}$ & 25 \\
\hline
\end{tabular}
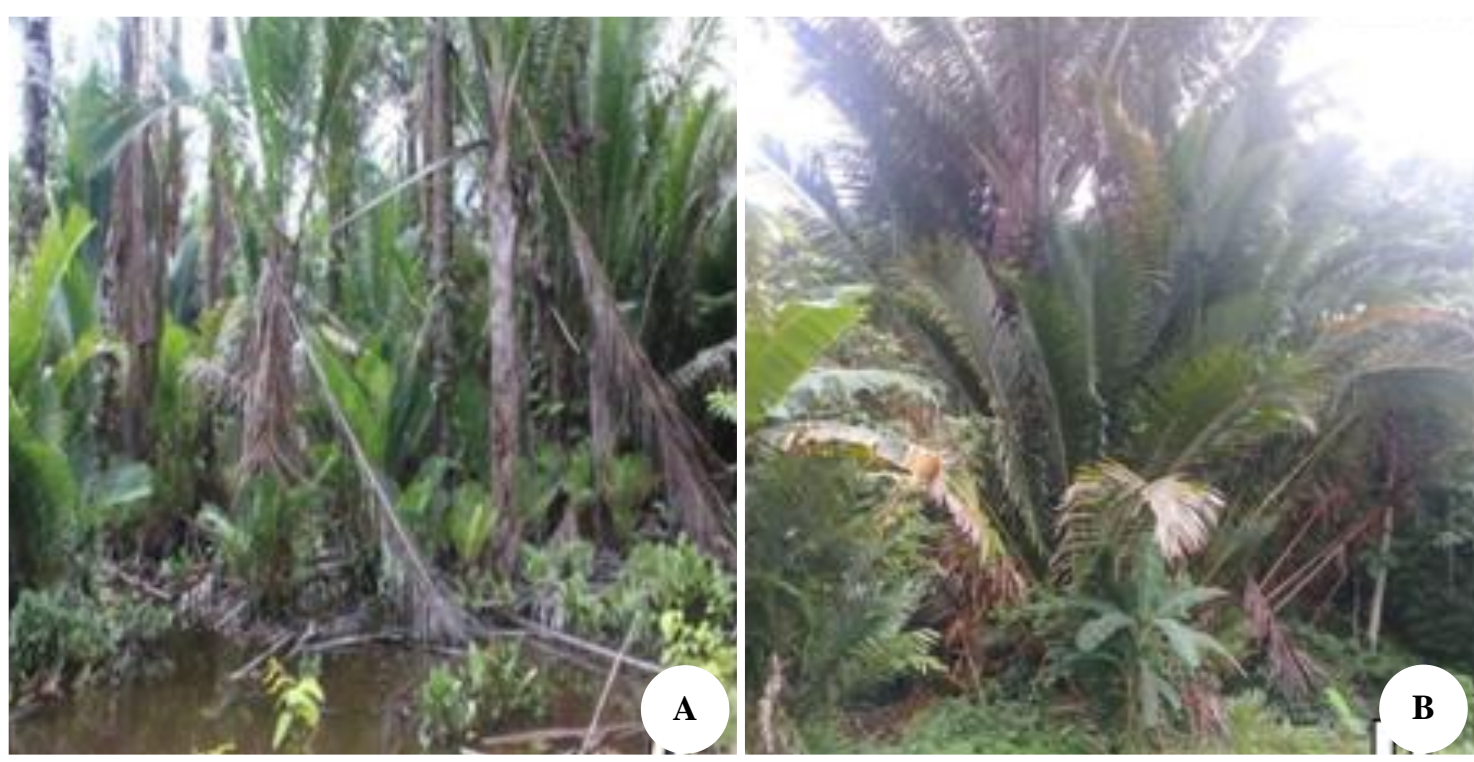

Figure 1. Sago palms used as samples. A. Temporarily inundated areas (TIA), B. Areas without inundation (WIA) 
The color of trunk surface looked the same in all varieties of sago palm. Based on vernacular names, sago palm has been reported to be consisting of a number of varieties. Similarly, each region in Papua in particular and Indonesia, in general, have plenty of sago palm names given by local people with different languages. Dewi et al. (2016) found 13 accessions in Saifi District, South Sorong District, which can be grouped into 2 categories, namely spiny and spineless. Abbas (2018) and Abbas et al. (2009) states that Papua is a center of diversity of sago palms and therefore, found a lot of accessions. Root characteristics of sago palms of TIA and WIA types were observed which showed that there is no difference in overall growth stages of sago palm. Miyazaki (2004) stated that before formation of trunk, the sago roots extend horizontally and after the formation of the trunk, the sago roots extend vertically. Small roots ( $<2 \mathrm{~mm}$ in diameter) are mostly concentrated on the ground, while large roots (> $2 \mathrm{~mm}$ in diameter) are concentrated in the soil. In addition, hairy roots were also found growing on the surface of the trunk which is highly humid due to the decaying midribs attached to the sago palm trunk. The phenomenon of hairy root growth on the surface of trunk was found in both TIA and WIA types of sago palms.

Comparison of morphological characteristics, such as length and color of petiole, length, and width of leaves, shape of leaves, and length of spines showed no differences between TIA and WIA types of sago palms. The leaves in middle position of midrib or petiole are the longest and shortest at the base and the end position on of the midrib. The longest leaves in the middle of midrib reach $123.8 \mathrm{~cm}$, while the shortest leaf at the end of midrib reaches $95.8 \mathrm{~cm}$ in the TIA type (Table 2). Statistical analysis of the leaf sizes of TIA and WIA types did not indicate any difference even if the number shows a view different. Average length of the midrib of the TIA type was $11.23 \mathrm{~m}$, while of the WIA types was a little shorter being $10.58 \mathrm{~m}$ (Table 2). Older leaves usually fall (senescence) and replaced by new leaves in the terminal. The leaf scar on the trunk generally drops, but some of the old midribs remain sticking to the trunk. The average leaf formation is around 2 leaves per month (Flach 1997). Leaf formation and growth patterns of sago palms is mainly influenced by genetic constitution (Riyanto et al. 2018). Canopy of sago palm in the trunk stage consists of several leaves in the form of midribs and leaflets that grow to form a spiral pattern around the growth point located in the middle of the crown shoot. Flach (1997) explained that petiole of sago palms has a length that ranges from 5-8 $\mathrm{m}$ and there are approximately 100200 leaves, with a length range of 1.0-1.5 m, depending on the conditions in the habitat of sago palm growth. Generally, morphology of sago palms in the rosette stages was clearly divided into four characters, i.e. spineless with green young leaf and red young leaf, spiny with green young leaf and red young leaf (Abbas et al. 2015).

Spines are present in certain sago palm varieties. The presence and size of spines are one of the characteristics that is often used by local people in South Sorong to distinguish the types of sago palm. Novero et al. (2012) explained the existence of spines on sago palm related to epigenetic events influenced by genetic and environmental factors. The influence of environmental factors is related to the content of methylated DNA especially in the condition of growth in temporary inundated area. Observations show that the spines in the rosette stage have longer size. The spine sizes decreased when the growth pattern of sago palm changes to trunk stages. In the trunk stage, spines appear to be hampered and shorter. In the TIA types, the average length of spines from the center, the second from the center, and the third from the center were 16.5, 8.1, and 1.6 $\mathrm{cm}$, respectively. The average spine length on the TIA type was not different from WIA type based on statistical analysis. According to information from the local community, the type of sago that was observed had a local name i.e. Fa Sampe, a type of long spine variety of sago palm. The spines on the midribs of trunk stages and rosette stages of sago palm are presented in Figure 2.

\section{Starch accumulation}

The trunk is an important part of sago which contains pith and starch (Bintoro et al. 2010). Statistical analysis of trunk diameters, bark thickness, bark weight, pith weight, wet starch weight, and dry starch weight showed that the effect of the place of growth was not significant on these aspects (Table 3). Average height of sago palm trunks of TIA type showed significant difference from that of WIA type, which was 11.20 and $12.63 \mathrm{~m}$, respectively (Table 3). Sago trunk growth of the WIA type was higher than the growth of the TIA type. Hypothetically, growth of the TIA type probably retarded when the habitat gets flooded. Flach (1997) stated that the sago trunk diameter ranges from 35 to $60 \mathrm{~cm}$ with a height of 6 to $16 \mathrm{~m}$, depending on variety and environmental conditions. Dewi et al. (2016) reported that twelve accessions of sago palms in South Sorong District showed the average height of trunks was $14.32 \mathrm{~cm}$, the highest of $16.24 \mathrm{~m}$ was shown by the accession of $\mathrm{Fa}$ Kreit and the lowest of $10.50 \mathrm{~m}$ was shown by Fa Sai's accession.

Table 2. Comparison of morphological characters of sago palms of the TIA and WIA type.

\begin{tabular}{|c|c|c|}
\hline \multirow{2}{*}{ Phenotypes } & \multicolumn{2}{|c|}{$\begin{array}{c}\text { Types of sago palm growth } \\
\text { area }\end{array}$} \\
\hline & TIA & WIA \\
\hline Petiole length (m) & $11.23^{\mathrm{ns}}$ & $10.58^{\mathrm{ns}}$ \\
\hline Petiole color & Green & Green \\
\hline Petiole surface, rosette stages & Spiny & Spiny \\
\hline $\begin{array}{l}\text { Leaf length }(\mathrm{cm}) \\
\text { Basal position on the midrib }\end{array}$ & $95.8^{\mathrm{ns}}$ & $96.0^{\text {ns }}$ \\
\hline Middle position on the midrib & $135.3^{\text {ns }}$ & $135.1^{\mathrm{ns}}$ \\
\hline $\begin{array}{l}\text { Upper position on the midrib } \\
\text { Leaf width of }(\mathrm{cm})\end{array}$ & $123.8^{\mathrm{ns}}$ & $125,6^{\mathrm{ns}}$ \\
\hline Basal position on the midrib & $7.9^{\text {ns }}$ & $8.0^{\mathrm{ns}}$ \\
\hline Middle position on the midrib & $9.8^{\mathrm{ns}}$ & $9.9^{\text {ns }}$ \\
\hline Upper position on the midrib & $11.9^{\mathrm{ns}}$ & $12.0^{\mathrm{ns}}$ \\
\hline Leaf color & Green & Green \\
\hline Length of spine $(\mathrm{cm})$ & & \\
\hline Central spine of the spine cluster & $16.5^{\mathrm{ns}}$ & $16.6^{\mathrm{ns}}$ \\
\hline The $2^{\text {nd }}$ spine from the center & $8.1^{\mathrm{ns}}$ & $7.3^{\mathrm{ns}}$ \\
\hline The $3^{\text {rd }}$ spine from the center & $1.6^{\mathrm{ns}}$ & $1.6^{\mathrm{ns}}$ \\
\hline
\end{tabular}

Notes: non-significant (ns), meter $(\mathrm{m})$, temporarily inundated area (TIA), without inundated area (WIA), centimeter (cm) 

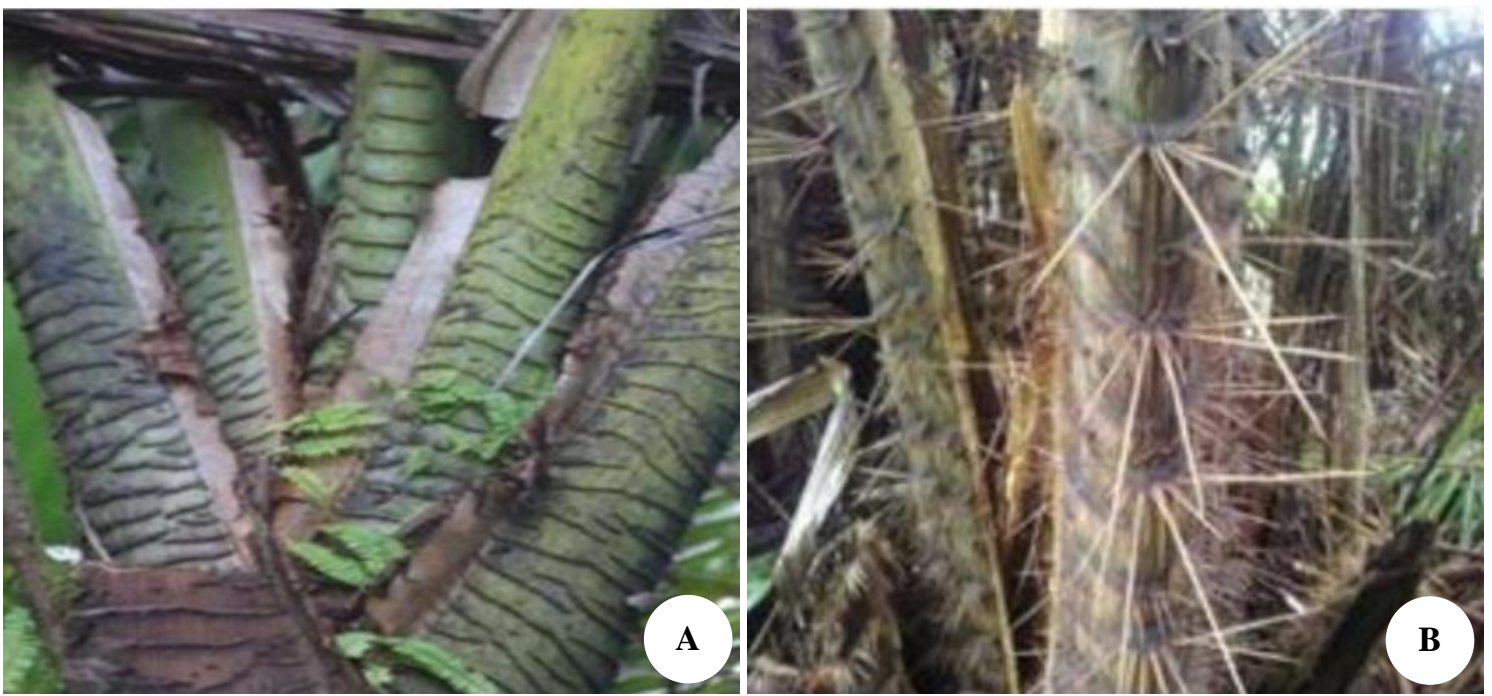

Figure 2. Appearance of spines on the surface of petiole. A. Spineless petiole in the trunk stage; B. Plenty of spines on petiole in rosette stages
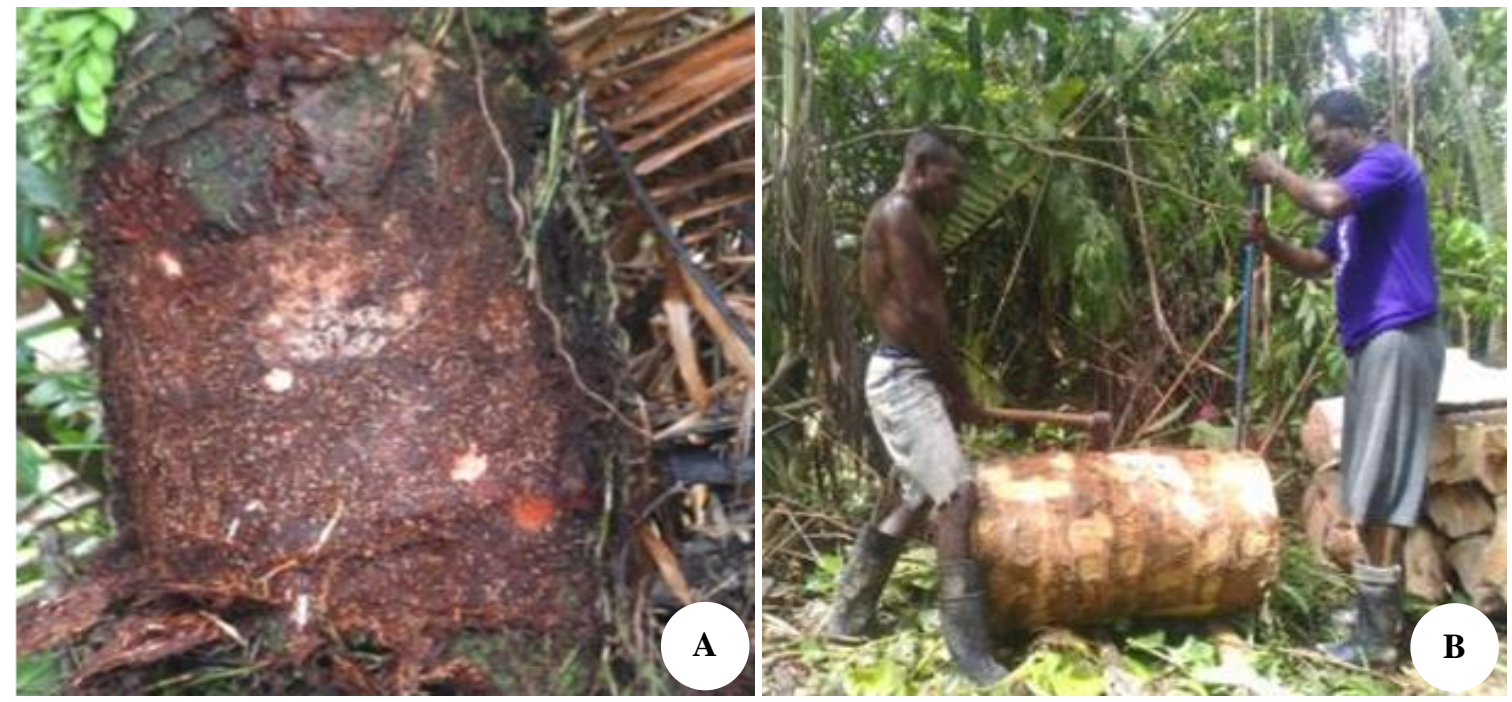

Figure 3. Appearance of the sago palm trunk. A. Before cutting down, B. After cutting down and pealing of bark

Furthermore, Notohadiprawiro and Louhenapessy (1992) explained that sago palms can grow in the land condition of stagnant water and non-stagnant water. Trunk formation of the sago palm that grows in the permanently water logged or stagnant water areas was found to be very slow which also affected production of starch. Average pith weight showed statistically significant differences between TIA and WIA types, which was 1266.99 and $1047.7 \mathrm{~kg}$, respectively (Table 3 ). This difference may be caused by difference in the water content of the pith. Sago palms of the TIA type probably absorbed more water, when the condition shifted to waterlogging.
Table 3. Trunk, bark and pith parameters (Average value) of sago palms of TIA and WIA Types

\begin{tabular}{lrr}
\multirow{2}{*}{ Variable } & \multicolumn{2}{c}{ Habitat type } \\
\cline { 2 - 3 } & \multicolumn{1}{c}{ TIA } & \multicolumn{1}{c}{ WIA } \\
\hline Trunk height $(\mathrm{m})$ & $11.20 \mathrm{a}$ & $12.63 \mathrm{~b}$ \\
Trunk diameter $(\mathrm{cm})$ & $62.03 \mathrm{~ns}$ & $63.58 \mathrm{~ns}$ \\
Bark thickness $(\mathrm{cm})$ & $1.82 \mathrm{~ns}$ & $2.04 \mathrm{~ns}$ \\
Bark weight $(\mathrm{kg})$ trunk-1 & $391.00 \mathrm{~ns}$ & $458.00 \mathrm{~ns}$ \\
Pith weight $(\mathrm{kg})$ trunk-1 & $1266.99 \mathrm{~b}$ & $1047.70 \mathrm{a}$ \\
Wet starch weight $(\mathrm{kg})$ trunk-1 & $478.67 \mathrm{~ns}$ & $460.00 \mathrm{~ns}$ \\
Dry starch weight $(\mathrm{kg})$ trunk-1 & $239.33 \mathrm{~ns}$ & $230.00 \mathrm{~ns}$
\end{tabular}

Notes: non-significant (ns), meter (m), temporarily inundated area (TIA), without inundated area (WIA), centimeter $(\mathrm{cm})$, kilogram $(\mathrm{kg})$. 
The average trunk diameter showed only a minor difference between TIA and WIA types which measured 62.03 and $63.58 \mathrm{~cm}$, respectively (Table 3). Differences of sago palms of the TIA type and WIA types vary depending on genetics and environmental conditions. Abbas et al. (2017) stated that sago palm derived directly from the seeds varied genetically which may be caused by crosspollination and this may cause growth differences. Riyanto et al. (2018) reported that growth of sago palm derived from seeds showed considerable variations. Sago palm grows faster and produces optimum starch when the environmental conditions are favorable, Several varieties of sago palm have high adaptability to the environment and will grow well in the waterlogged areas (Haryanto and Pangloli 1992). Dewi et al. (2016) reported that sago palms in the district Saifi, South Sorong were able to produce more than $200 \mathrm{~kg} /$ trunk of dry starch, depending on their varieties.

Starch accumulation in sago palm trunks was found to be lower in the middle and upper parts, and highest starch accumulation was found in the middle part. The average wet starch accumulation in the middle part was $182.67 \mathrm{~kg}$ which was found to be significantly different from that of lower and upper parts with an average accumulation of 145.00 and $151.00 \mathrm{~kg}$, respectively (Table 4). This uneven starch distribution pattern in the trunks of sago palms was observed in both TIA and WIA types. An uneven pattern of starch distribution along the trunk was also reported by Jong (1995). He also reported that the highest starch accumulation in sago trunk was in the middle part. The dry starch content also followed the pattern of wet starch distribution along the trunks of both TIA and WIA types. The average of dry starch in the lower, middle and upper part of the trunk of TIA type palms was found to be 72.5, 91.3 and $75.5 \mathrm{~kg}$ respectively. Ehara (2009) reported that starch accumulation showed positive correlation with trunk weight and size. The average diameter of the trunk in the center of the sago palm is larger than the lower trunk but not significantly different from the upper trunk. This indicates that the diameter size of the sago palm trunk affects the starch content. Muhidin et al. (2016) reported the results of their research in Southeast Sulawesi Kendari that the production of sago starch in habitats without inundation was lower than that of habitat with temporary inundation. Nozaki et al. (2004) reported that starch accumulation in the sago trunks growing in acidic and mineral soils was different. In sago palm that grows in mineral soils, most of the starch accumulates below $6.0 \mathrm{~m}$ height, with maximum starch accumulation in $3.0-3.5 \mathrm{~m}$ height, and almost no starch in the upper part (8.5-9.2 m). Conversely, in acidic soil, the starch concentration was higher at the top part of the trunk, with maximum in the trunk part of 7.0-7.8 $\mathrm{m}$ above ground level.

Color of starch powder produced by palms of both locations showed no differences between them. The color of starch of both TIA and WIA types was yellowish white (RGB158C or hexRGB: fbe5cb) (Figure 4). The starch color of sago palms of TIA and WIA types is slightly different from starch color that was reported by earlier researchers. Dewi et al. (2016) reported the characteristics of starch color of sago palm in the South Saifi Sorong district was influenced by bark color that was Pink (5YR8/3). The quality of sago starch is influenced by genetic factors and extraction processes, such as water used and filtering (Flach 1997). According to Purwani et al. (2006), the degree of whiteness of sago starch varies and can turn brown or reddish during storage. This color change is due to the activity of the enzyme Latent Polyphenol Oxidase (LPPO)that catalyzes the oxidation reaction of polyphenol compounds to quinones which then form polymers and produce brown color (Onsa et al. 2000). According to Haryadi (2002), white starch of sago palm can be obtained by spraying water at the time of mixing.

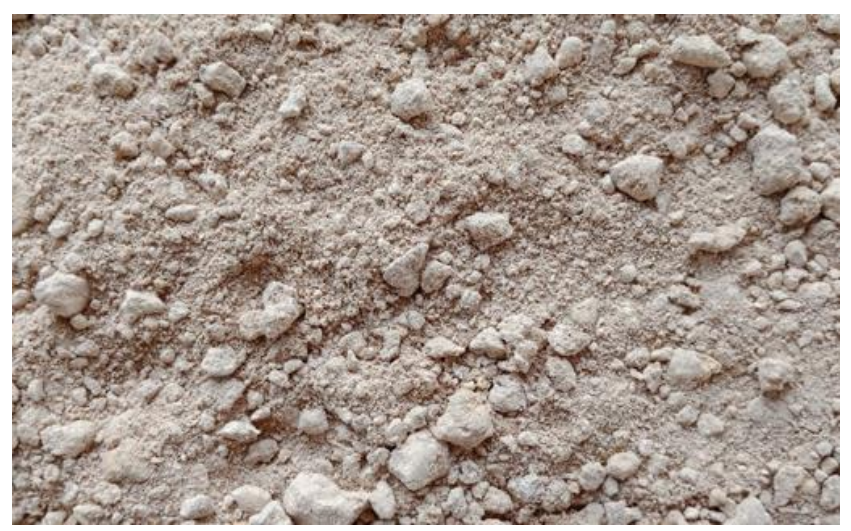

Figure 4. Starch characteristics of sago palm in both TIA and WIA types

Table 4. Average values of dimensions and starch accumulation in the lower, middle, and upper parts of sago palm trunks of TIA and WIA types

\begin{tabular}{|c|c|c|c|c|c|c|}
\hline \multirow[b]{2}{*}{ Variable } & \multicolumn{3}{|c|}{ TIA type } & \multicolumn{3}{|c|}{ WIA type } \\
\hline & $\begin{array}{l}\text { Lower } \\
\text { trunk }\end{array}$ & $\begin{array}{c}\text { Middle } \\
\text { trunk }\end{array}$ & $\begin{array}{l}\text { Upper } \\
\text { trunk }\end{array}$ & $\begin{array}{c}\text { Lower } \\
\text { trunk }\end{array}$ & $\begin{array}{c}\text { Middle } \\
\text { trunk }\end{array}$ & $\begin{array}{l}\text { Upper } \\
\text { trunk }\end{array}$ \\
\hline Trunk diameter $(\mathrm{cm})$ & $58.28^{\mathrm{a}}$ & $63.90^{\mathrm{b}}$ & $63.90^{\mathrm{b}}$ & $60.08^{a}$ & $65.08 \mathrm{~b}$ & $65.60^{\mathrm{b}}$ \\
\hline Bark thickness $(\mathrm{cm})$ & $1.91^{\mathrm{b}}$ & $1.91 \mathrm{~b}$ & $1.63^{\mathrm{a}}$ & $2.27^{\mathrm{b}}$ & $1.99^{\mathrm{a}}$ & $1.87^{\mathrm{a}}$ \\
\hline Bark weight $(\mathrm{kg})$ trunk part ${ }^{-1}$ & $147.00^{\text {ns }}$ & $137.00^{\text {ns }}$ & $107.00^{\text {ns }}$ & $186.00^{\mathrm{ns}}$ & $134.33^{\text {ns }}$ & $137.67^{\mathrm{ns}}$ \\
\hline Pith weight $(\mathrm{kg})$ trunk part ${ }^{-1}$ & $322.33^{\mathrm{a}}$ & $468.33^{\mathrm{b}}$ & $458.33^{\mathrm{b}}$ & $255.70^{\mathrm{a}}$ & $349.00^{\mathrm{b}}$ & $443.00^{\mathrm{b}}$ \\
\hline Wet starch weight $(\mathrm{kg})$ trunk part ${ }^{-1}$ & $145.00^{\mathrm{a}}$ & $182.67^{b}$ & $151.00^{\mathrm{a}}$ & $140.67^{\mathrm{a}}$ & $175.33^{b}$ & $144.00^{\mathrm{a}}$ \\
\hline Dry starch weight $(\mathrm{kg})$ & $72.50^{\mathrm{a}}$ & $91.33^{\mathrm{b}}$ & $75.50^{\mathrm{a}}$ & $70.33^{\mathrm{a}}$ & $87.67^{\mathrm{b}}$ & $72.00^{\mathrm{a}}$ \\
\hline
\end{tabular}

Note: Numbers followed by the same letters on the same line are not significant differences based on statistical analysis at the level of $\alpha$ $=0.05$ 
In conclusion, the study indicated that morphological characters and starch production of sago palms growing in temporarily inundated and non-inundated habitats did not show any differences. The distribution of starch along the sago trunk was uneven, the higher starch accumulation was found in the middle part of the trunk which was significantly different from the lower and upper part of the trunk.

\section{ACKNOWLEDGEMENTS}

Part of this research was funded by the National Strategy Institution Research Project entitled "Development of Sago Palm Agroindustry to Accelerate the Realization of Food Security" under contract No.080/SP2H/LT/DRPM/2018. Authors also thank the National Strategy Institution Research project manager for managing this project.

\section{REFERENCES}

Abbas B, Bintoro HM, Sudarsono, Surahman M, Ehara H. 2009. Genetic relationship of sago palm (Metroxylon sagu Rottb.) in Indonesia based on RAPD markers. Biodiversitas 10 (4): 168-174.

Abbas B, Paisey EK, Bachri S, Edowai DN, Ehara H.2014. Genetic diversities of sago palm forest in South Sorong, West Papua, Indonesia based on RAPD markers. Conf Soc Sago Palm Stud 23 31-32.

Abbas B, Listyorini FH, Munarti. 2015. Genetic diversity of eleven sago palm accessions from SRC's Germ Plasm based on mitochondrial atp 6-2 genes and introns. In: Ehara H, Toyoda Y, Mishima T, Naito H, Kakuda K, Nakamura S (eds.) The Sago Supports Human Planet Welfare. Proc $12^{\text {th }}$ Int Sago Symp, Rikkyo University, Tokyo, Japan September 15-16, 2015.

Abbas B, Dailami M, Santoso B, Munarti. 2017. Genetic variation of sago palm (Metroxylon sagu Rottb.) progenies with natural pollination by using RAPD markers. Nat Sci 7(4): 104-109.

Abbas B. 2018. Sago palm genetic resource diversity in Indonesia. In Ehara H (eds.) Sago Palm: Multiple Contributions to Food Security and Sustainable Livelihood. Springer, Berlin.

Bintoro MH, Purwanto MYJ, Amarillis S. 2010. Sago in peatland. IPB Press, Bogor. [Indonesian]

Bintoro MH, Mashud N, Novarianto H. 2007. Sago technology status (Metroxylon spp.) Proceeding of Sago Palm Symposium in Indonesia. Research Center of Plantation Development, Bogor. [Indonesia]

BPPT. 2014. Final report of master plan of sago palm development in South Sorong District. Collaboration with BPPT and BAPPEDA South Sorong District. [Indonesian]
Dewi RK, Bintoro MH, Sudrajat. 2016. Morphological characteristics and yield potential of sago palm (Metroxylon spp.) accessions in South Sorong District, West Papua. J Agron Indonesia 44: 91-97. [Indonesian]

Ehara H. 2009. Potency of sago palm as carbohydrate resource for strengthening food security program. J Agron Indonesia 37 (3): 209219.

Flach M. 1983. The sago palm. FAO Plant Production and Protection Paper 47. FAO, Rome.

Flach M. 1997. Sago Palm. International Plant Genetic Resources Institute (IPGRI) Promoting the Conservation and Use of Underutilized and Neglected Crops, 13. IPGRI Italy and IPK Germany.

Haryadi. 2002. The Current Status and Future Prospects of Sago Palm in Java. New Frontiers of Sago Palm Studies. Universal Academic Press, Inc., Tokyo.

Haryanto B, Pangloli. 1992. Potency and utilization of sago palm. Kanisius, Yogyakarta. [Indonesia]

Ihalauw O. 2015. Potency of sago palm forest in South Sorong needs to manage and utilize sustainability for increasing prosperity of community in South Sorong. In: Ehara H, Toyoda Y, Mishima T, Naito H, Kakuda K, Nakamura S (eds.) The Sago Supports Human Planet Welfare. Proc $12^{\text {th }}$ Int Sago Symp, Rikkyo University, Tokyo, Japan September 15-16, 2015.

Jong FS. 1995. Research for the development of sago palm (Metroxylon sagu Rottb.) cultivation in Sarawak, Malaysia. Dept. Agriculture, Kuching, Sarawak, Malaysia.

Kertopermono AP. 1996. Inventory and evaluation of sago palm (Metroxylon sp) distribution. Sixth International Sago Symposium. Pekan Baru, 9-12 December 1996.

Miyazaki A. 2004. Studies on differences in photosynthetic abilities among varieties and related characters in sago palm (Metroxylon sagu Rottb.) in Indonesia. Faculty of Agriculture, Kochi University, Kochi, Japan.

Muhidin, Sitti L, Syamsu A. Teguh W. 2016. Comparative studies on different agroecosystem base on soil physicochemical properties to development of sago palm on dry land. Intl J Chem Tech Res 9(08): 511-518.

Notohadiprawiro T, Louhenapessy JE. 1992. Potency of sago palm as a diversification staple food in consideration land requirement. National Sago Palm Symposium. Carried out by UNPATTI, PEMDA Maluku and BPPT in Ambon. Oktober 12-13,1992. [Indonesian]

Novero AU, Mabras MB, Esteban HJ. 2012. Epigenetic inheritance of spine formation in sago palm (Metroxylon sagu Roettb). Plant Omics J 5 (6): 559-566.

Nozaki K, Nuyim T, Shinano T, Hamada S, Ito H, Matsui H, Osaki M. 2004. Starch properties of the sago palm (Metroxylon sagu Rottb.) in Different Soils. Plant Foods Hum Nutr 59: 85-92.

Onsa GH, Saari N, Selamat J, Bakar J. 2000. Latent polyphenol oxidases from sago log (Metroxylon sagu); partial purification, activation, and some properties. J Agric Food Chem 48: 5.041-5.045.

Purwani EY, Widaningrum, Setiyanto H, Savitri E, Thahir R. 2006. Noodles processing technology. Balai Besar Penelitian dan Pengembangan Pascapanen Pertanian, Bogor. [Indonesian]

Riyanto R, Widodo I, Abbas B. 2018. Morphology, growth and genetic variations of sago palm (Metroxylon sagu) seedlings derived from seeds. Biodiversitas 19: 602-608. 